$1-1-2013$

\title{
Is the Corporate Director's Duty of Care A "Fiduciary' Duty? Does It Matter?
}

Christopher M. Bruner

University of Georgia School of Law, christopher.bruner@uga.edu

P bepress $S$ SRN

\section{Repository Citation}

Christopher M. Bruner, Is the Corporate Director's Duty of Care A "Fiduciary' Duty? Does It Matter? , 48 Wake Forest L. Rev. 1027 (2013),

Available at: https://digitalcommons.law.uga.edu/fac_artchop/1134

This Article is brought to you for free and open access by the Faculty Scholarship at Digital Commons @ University of Georgia School of Law. It has been accepted for inclusion in Scholarly Works by an authorized administrator of Digital Commons @ University of Georgia School of Law. Please share how you have benefited from this access For more information, please contact tstriepe@uga.edu. 


\title{
IS THE CORPORATE DIRECTOR'S DUTY OF CARE A "FIDUCIARY" DUTY? DOES IT MATTER?
}

\author{
Christopher M. Bruner*
}

\section{INTRODUCTION}

In an article appearing in the Wake Forest Law Review several years ago, I argued that Delaware's nascent corporate law duty of "good faith" ought to be conceptualized as a component of the duty of loyalty, the logic being that the former conceptual vessel could contain no content not wholly redundant with the latter. ${ }^{1}$ This position-strenuously advocated for years by then-Vice Chancellor Leo Strine-was ultimately adopted by the Delaware Supreme Court in its 2006 Stone v. Ritter opinion. ${ }^{2}$ In the same piece, I further argued that Delaware ought to clarify the conceptual boundary between the corporate director's duties of care and loyalty by adopting a statutory provision "permitting the imposition of monetary liability only for loyalty breaches, defined to include cases involving financial conflicts of interest, other improper personal benefits, conscious malfeasance, and conscious nonfeasance, the latter category representing those cases [now] styled by the Delaware courts as involving bad faith omission." 3 This positionclearly more controversial and far-reaching, effectively discarding much of Delaware's multilayered and convoluted mode of analysis for the duty of care ${ }^{4}$ - has not been adopted by the Delaware General Assembly.

* Professor of Law and Ethan Allen Faculty Fellow, Washington and Lee University School of Law. This Essay was presented at the 2013 Fiduciary Law Workshop at Notre Dame Law School and benefited greatly from discussion in that forum. For helpful comments and suggestions, many thanks to Evan Criddle, Evan Fox-Decent, Tamar Frankel, Andrew Gold, Lyman Johnson, Paul Miller, David Millon, and Julian Velasco. All errors or omissions are, of course, mine.

1. See generally Christopher M. Bruner, Good Faith, State of Mind, and the Outer Boundaries of Director Liability in Corporate Law, 41 WAKE FOREST L. REV. 1131 (2006).

2. 911 A.2d 362, 369-70 (Del. 2006) (citing Strine to support this conclusion); see also Bruner, supra note 1, at 1159-62 (examining Strine's position); $i d$. at 1184-86 (examining Stone $v$. Ritter in a postscript added before press).

3. Bruner, supra note 1, at 1136 (emphasis omitted).

4. See id. at $1177-84$. 
In this Essay I return to the topic, exploring further the merits of this proposal as well as the conceptual and practical impediments that might stand in the way-a reexamination prompted by comparative work on corporate governance in common law jurisdictions that $I$ have undertaken in the intervening years. Though not emphasizing the duty of care as such, ${ }^{5}$ this comparative work brought to my attention a curious divergence in this areaunlike the United States, other common law jurisdictions including the United Kingdom, Australia, and Canada generally do not conceptualize the duty of care as "fiduciary" in nature. 6 While the inquiry undertaken in this Essay focuses more intently on the United States, ${ }^{7}$ I discuss this divergence because it vividly demonstrates the noninevitability of characterizing the duty of care as a "fiduciary" duty while simultaneously suggesting that there may be practical utility in drawing a clear distinction between duties of care and loyalty in this manner.

Indeed, this contrast between the U.S. approach and that of other common law jurisdictions prompts some important questions about Delaware's doctrinal structure. Specifically, has the evolution of Delaware's convoluted framework for evaluating disinterested board conduct-involving an articulation of a duty of care, which was effectively negated by the business judgment rule, revived by the "gross negligence" standard for overcoming the business judgment rule, then negated again by statutory exculpation, yet potentially revived again by statutory exceptions to exculpation ${ }^{8}$ been facilitated by styling the duty of care a "fiduciary" duty? If so,

5. These works examine varying degrees of shareholder orientation in common law jurisdictions and therefore focus on shareholders' governance powers and the intended beneficiaries of board decision making. See generally CHRISTOPHER M. BRUNer, CORPorate GOVERNANCE IN THE COMMON-LAW WORLD: The Political Foundations of Shareholder Power (2013); Christopher M. Bruner, Power and Purpose in the "Anglo-American" Corporation, 50 VA. J. INT'L L. $579(2010)$.

6. On the United Kingdom, see, for example, PaUl L. DAviEs, GowER AND DAVIES' PRINCIPLES OF MODERN COMPANY LAW 488-97 (8th ed. 2008); ALAN DigNaM \& JoHN LOWRY, COMPANY LAW 300-01, 320-24 (2009); Nigel Banerjee, Fiduciary Duties of Directors, in [79 Company Law] Butterworths Corp. Law Serv. (LexisNexis Butterworths) ๆ $25.23-.49$ (Dec. 20, 2012); Simon Graham, The Duty of Care, Skill and Diligence, in [79 Company Law] Butterworths Corp. Law Serv., supra, at ๆף 24.207-.220. On Australia, see, for example, ROBERT P. AUSTIN \& IAN M. RAMSAY, FORD'S PRINCIPLES OF CORPORATIONS LAW 364, 437-42 (14th ed. 2010). On Canada, see, for example, BRUCE WELLING, CoRPorate LAW In CANadA: The Governing Principles 327-31, 368 n.235 (3d ed. 2006); Paul B. Miller, A Theory of Fiduciary Liability, 56 McGILL L.J. 235, 256-59, 269-70, 281 (2011).

7. For a discussion of contextual challenges faced in the comparative study of corporate governance-particularly where the aim is to identify normatively superior modes of corporate regulation-see BRUNER, supra note 5, at $13-27$.

8. See Bruner, supra note 1 , at 1133-36. 
then what-if anything-ought Delaware lawmakers and judges to do about this problem moving forward?

I argue that styling care a "fiduciary" duty has in fact impacted the evolution of Delaware's duty of care in ways that are not uniformly positive. Historically, the duty of loyalty has been more aggressively enforced, while the duty of care has hardly been enforced at all-the former approach aiming principally to reduce conflicts of interest through probing analysis of "entire fairness," and the latter aiming principally to promote entrepreneurial risk taking through a hands-off judicial posture embodied most clearly in the business judgment rule. Conflation of these differing circumstances and problems as "fiduciary duties" (plural) or as twin reflections of a "fiduciary" concept (singular) has resulted in a tendency toward overenforcement of the corporate director's duty of care, periodically threatening to impair entrepreneurial risk taking until arrested by a countervailing legislative or judicial response. Additionally, the conflation of care and loyalty threatens to facilitate exosion of the corporate director's duty of loyalty (a trend readily discernible in noncorporate settings) by fueling the contractarian argument that the sole utility of "fiduciary duties" is to fill gaps in incomplete contracts-an argument suggesting that corporate stakeholders ought to have the same latitude to "opt out" of loyalty that they effectively possess with respect to care and that disloyalty involves no greater moral stigma than any garden-variety breach of contract.

While I ultimately concede that there may be no pressing imperative to restyle the duty of care in nonfiduciary terms moving forward-and that there may in fact be good reasons not to do so-I conclude that the analytical problems described in this Essay can otherwise be remedied only through a statutory provision that more clearly distinguishes these differing duties and enforcement strategies from one another, foreclosing their further conflation in a categorical manner.

\section{DisinTERESTED DiRECTORS' LIABILITY EXPOSURE IN DELAWARE}

Delaware's doctrinal framework for duty of care analysis is hardly a picture of clarity; in fact, as I have argued in prior work, it is almost precisely the opposite. $9^{9}$ Analytically, one begins with the proposition that Delaware directors owe a duty of care, defined by reference to the traditional reasonable prudence standard. ${ }^{10}$ This

9. For additional background on the doctrinal evolution described here, see Bruner, supra note 1 , at 1132-37, 1150-59.

10. See Graham v. Allis-Chalmers Mfg. Co., 188 A.2d 125, 130 (Del. 1963) ("[D]irectors of a corporation in managing the corporate affairs are bound to use that amount of care which ordinarily careful and prudent men would use in similar circumstances."); see also Lyman Johnson, Rethinking Judicial Review 
duty is substantially qualified in practical effect, however, by the socalled "business judgment rule" ("BJR"), which insulates disinterested decisions aimed at the company's best interests from after-the-fact judicial scrutiny or monetary damages-a judicial posture typically attributed to a desire to promote entrepreneurial risk taking by foreclosing negligence-based liability threats, the prospect of which might otherwise result in substantial risk aversion. ${ }^{11}$ In Delaware, the BJR has been styled "a presumption that in making a business decision the directors of a corporation acted on an informed basis, in good faith and in the honest belief that the action taken was in the best interests of the company." 12

The Delaware Supreme Court explained in its 1984 Aronson v. Lewis opinion that "directors have a duty to inform themselves, prior to making a business decision, of all material information reasonably available to them" and indicated that the BJR's protection could be overcome by a showing of "gross negligence" in this regard.13 Historically, however, the market's understanding was that the BJR effectively barred recovery for breach-of-care claims, rendering the Delaware Supreme Court's finding of gross negligence in the approval of a merger in its 1985 Smith v. Van Gorkom decision ${ }^{14}$ a quite literal shock to the business community. The Delaware General Assembly reacted swiftly to the ensuing uproar (and associated disruption to the directors and officers liability insurance market) through the enactment of section 102(b)(7) in July 1986. ${ }^{15}$ This provision of the Delaware General Corporation Law permits a Delaware corporation's charter to include a "provision eliminating or limiting the personal liability of a director to the corporation or its stockholders for monetary damages for breach of fiduciary duty," except where the director's conduct involved loyalty breaches, "acts or omissions not in good faith or which involve intentional misconduct or a knowing violation of law," unlawful distributions, or transactions involving "an improper personal benefit." 16 This provision has been broadly (and accurately) understood from the beginning as a direct response to the turmoil created by the Van Gorkom decision, permitting

of Director Care, 24 DEL. J. CoRP. L. 787, 793-94 (1999) (observing that clear Delaware authority to this effect was surprisingly sparse before the $1960 \mathrm{~s}$ ).

11. See, e.g., Gagliardi v. TriFoods Int'l, Inc., 683 A.2d 1049, 1051-53 (Del. Ch. 1996); see also infra Part IIV.

12. Aronson v. Lewis, 473 A.2d 805, 812 (Del. 1984), overruled on other grounds by Brehm v. Eisner, 746 A.2d 244 (Del. 2000).

13. Id.

14. Smith v. Van Gorkom, 488 A.2d 858, 874 (Del. 1985), overruled on other grounds by Gantler v. Stephens, 965 A.2d 695 (Del. 2009).

15. For a discussion of the events leading up to the passage of this provision, see Bruner, supra note 1, at 1139-44.

16. DEL. CODE ANN. tit. $8, \S 102(b)(7)(2011)$. 
Delaware corporations to revert to the status quo ante one by onewhich most have in fact done. ${ }^{17}$

Section 102(b)(7)'s exceptions, however-suggesting through separate enumeration that "good faith" meant something distinct from "loyalty"-led to a long and tortured debate over the scope of the "good faith" concept and its role in policing board conduct. The principal impetus for this debate was the effort of enterprising plaintiffs' lawyers to bring cases of omission-notably, alleged oversight failures-within section 102(b)(7)'s "good faith" exception, rendering damages available notwithstanding the adoption of an exculpatory charter provision. ${ }^{18}$ This debate was not laid to rest until 2006, when Stone v. Ritter established that good faith is a component of loyalty and that imposing liability for a bad faith omission requires meeting the exacting Caremark standard, under which "only a sustained or systematic failure of the board to exercise oversight ... will establish the lack of good faith that is a necessary condition to liability."19

There are two critical observations to draw from this history. First, Delaware's doctrinal structure for evaluating the adequacy of disinterested directors' conduct has, since the 1980s, continually grown by accretion, piling complexity upon complexity, with each development tending to augment disinterested directors' liability exposure being undone by the next development. Second, at no point have the courts or the Delaware General Assembly meaningfully sought to distill this framework down to its essence.

To be sure, there are areas in which such a swinging-pendulum dynamic could plausibly be described as refining the relevant doctrinal structure over time. ${ }^{20}$ For example, in its takeover jurisprudence, the Delaware Supreme Court broadly legitimated target boards' use of defensive measures, including poison pills, ${ }^{21}$ then carved back at the availability of such defenses in certain finalperiod circumstances by imposing heightened duties on target

17. See Bruner, supra note 1 , at 1144-46, 1182-83 (noting that $\S 102(b)(7)$ has led most Delaware corporations to adopt exculpatory charter provisions); see also Douglas M. Branson, Assault on Another Citadel: Attempts to Curtail the Fiduciary Standard of Loyalty Applicable to Corporate Directors, 57 FoRDHAM L. REv. 375, 381 (1988) (observing that the "trend began in the 1987 annual meeting season, when American corporations in great number sought to implement the law's new liberality by seeking shareholder approval for opt out provisions in articles of incorporation").

18. For a detailed discussion see Bruner, supra note 1, at 1150-73.

19. See Stone v. Ritter, 911 A.2d 362, 369-70 (Del. 2006) (quoting In re Caremark Int'l Inc. Derivative Litig., 698 A.2d 959, 971 (Del. Ch. 1996)); see also Christopher M. Bruner, Good Faith in Revlon-Land, 55 N.Y.L. ScH. L. Rev. 581, 584-89 (2010/11); Bruner, supra note 1, at 1184-86.

20. I am indebted to my colleague David Millon for suggesting the following comparison.

21. See Moran v. Household Int'l, Inc., 500 A.2d 1346, 1354 (Del. 1985); Unocal Corp. v. Mesa Petroleum Co., 493 A.2d 946, 955 (Del. 1985). 
boards, ${ }^{22}$ and then provided guidance on how target boards could avoid triggering such duties, thereby retaining their discretion to implement defenses. ${ }^{23}$ Whatever the substantive merits of this approach to takeover regulation may be (regarding which reasonable minds continue to differ), ${ }^{24}$ this approach nicely illustrates the potential for a swinging-pendulum dynamic in case law to refine the doctrine over time-a dynamic reflecting the underlying logic of the common law method itself. 25

The key for our purposes, however, is to observe that no such process of refinement has unfolded in Delaware's duty of care jurisprudence, where the dynamic would be more accurately described as vacillation. Indeed, it is quite arguably (and ironically) the case that, for the vast majority of Delaware corporations, the developments described above net out to an overall degree of liability exposure for disinterested directors that is not materially different from the exposure faced by their forebears prior to Aronson and Van Gorkom-which is to say, virtually none. Depicted as vectors tending toward greater or lesser liability exposure, as the case may be, the doctrinal landscape today looks something like the following: 26

\section{LIABILITY EXPOSURE FOR DISINTERESTED DIRECTORS' CONDUCT}

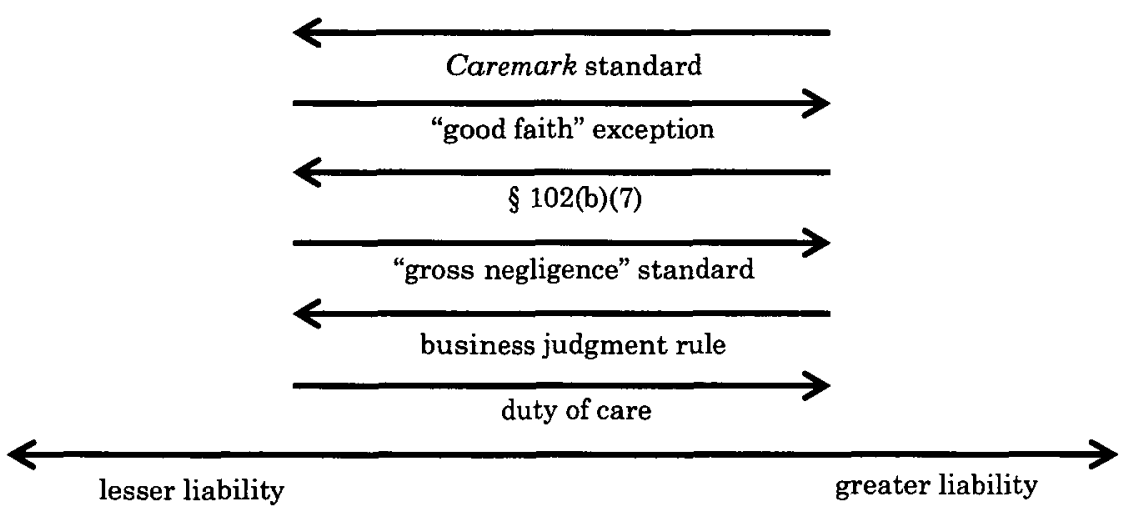

22. See Revlon, Inc. v. MacAndrews \& Forbes Holdings, Inc., 506 A.2d 173, 185 (Del. 1986).

23. See Paramount Commc'ns, Inc. v. Time Inc., 571 A.2d 1140, 1152-53 (Del. 1990).

24. On the compatibility of Delaware's hostile takeover case law with various theories of U.S. corporate governance, see Christopher M. Bruner, The Enduring Ambivalence of Corporate Law, 59 ALA. L. REV. 1385, 1395-408 (2008).

25. For a discussion of the scope and strength of "precedential constraint" in common law cases, see Larry Alexander, Precedent, in A CoMPANION to Philosophy of LAW AND Legal Theory 503 (Dennis Patterson ed., 1996).

26. This figure updates the figure included in Bruner, supra note 1 , at 1136. Note that while Delaware's BJR historically predated clear articulation of a director's duty of care, it remains coherent today to present the duty of care as analytically prior. See infra note 78 . 
As the figure depicts, imposing a duty of care gave rise to the possibility that disinterested directors could face monetary liability exposure, but this theoretical possibility was effectively negated by the BJR as applied until the 1980s. The broadly read "gross negligence" standard announced in Aronson (and applied in Van Gorkom), however, resurrected the possibility of such liability exposure, but this renewed exposure was then itself effectively negated by section 102(b)(7). The broadly read "good faith" exception to section 102(b)(7) resurrected the possibility of monetary liability exposure for disinterested directors yet again, but this form of exposure was itself effectively negated by the exacting Caremark standard (widely-and correctly-understood to be exceedingly difficult for plaintiffs to meet). ${ }^{27}$

At the end of the day, the doctrinal framework for the duty of care described above nets out to a virtual rejection of monetary liability in the absence of a conflict of interest. Yet, the byzantine complexity of this structure remains problematic for at least three reasons: (1) it preserves traps for the unwary; (2) it continues to invite wasteful litigation at multiple junctures; and (3) it preserves the potential for further swings of the pendulum, toying with the notion of liability exposure for disinterested directors pending definitive (and inevitable) rejection of this possibility by courts or the legislature, resulting in further growth by accretion following the well-established pattern described above. The statutory response described earlier would remedy this by, in essence, netting the vectors once and for all, formally declaring the unavailability of monetary damages for breaches of the duty of care-a step that would eliminate the need for a BJR in the context of director liability (with its vague and troublesome "gross negligence" standard), section 102(b)(7) (with its vague and troublesome "good faith" exception and pointless reliance on one-off charter provisions), and insurance coverage for directors' care exposure, all at once. 28

The remainder of this Essay explores whether styling the duty of care a "fiduciary" duty may have facilitated the emergence and growth of this framework and how recognition of such dynamics ought to impact Delaware's response moving forward.

\section{The Disputed Nature of THE DUTY OF CARE}

While reference to a director's "fiduciary duties" (plural) is routinely employed as a convenient shorthand for corporate directors' duties of care and loyalty in the United States, our tendency to conflate the two in this manner is in fact unique-even among the common law systems with which our own is most often

27. See Bruner, supra note 1, at 1133-36; see also Bruner, supra note 19 , at $584-89$.

28. Bruner, supra note 1 , at $1177-84$. 
compared. ${ }^{29}$ In the United Kingdom, for example, loyalty stands alone as the "fiduciary duty" (singular). A U.K. director's duties, as specified in the Companies Act 2006, ${ }^{30}$ would, to be sure, appear broadly familiar to an American corporate lawyer. The director must "act in accordance with the company's constitution" (its core governance document), ${ }^{31}$ "promote the success of the company," 32 "exercise independent judgment," 33 avoid conflicts of interest (and declare any that may arise), ${ }^{34}$ and, of course, "exercise reasonable care, skill and diligence." ${ }_{35}$ The first several duties listed above are all recognizable expressions of the duty of loyalty, ${ }^{36}$ while the last obviously represents the duty of care. When it comes to enforcement, however, an important distinction is drawn between them. Section 178 explains that the "consequences of breach" of these various duties "are the same as would apply if the corresponding common law rule or equitable principle applied." 37 The provision goes on to explain, then, that this means that all of these duties, "with the exception of [the] duty to exercise reasonable care, skill and diligence," are "enforceable in the same way as any other fiduciary duty owed to a company by its directors." 38 This provision of the Companies Act preserves the traditional distinction between breach of "fiduciary duty" - that is, the duty of loyalty-for which "restitutionary or restorative remedies" are available, and breach of the duty of care, for which the "standard remedy ... is

29. See BRUNER, supra note 5, at 3-12 (discussing the tendency to overstate the similarities among the corporate governance systems of common law jurisdictions).

30. c. $46, \S \S 170-77$ (U.K.).

31. Id. $\S 171(\mathrm{a})$.

32. Id. $\S 172(1)$.

33. Id. $\S 173(1)$.

34. Id. $\S \S 175-77$.

35. Id. $\S 174(1)$.

36. As my characterization of these provisions suggests, I use the term "loyalty" broadly to require not only avoidance of conflicts but also affirmative commitment to advance the company's best interests. See generally Bruner, supra note 1. This is the approach now endorsed by the Delaware Supreme Court. See Stone v. Ritter, 911 A.2d 362, 369-70 (Del. 2006). It must be acknowledged, however, that in fiduciary law more generally, the specific content of the duty of loyalty remains contested. See, e.g., Andrew S. Gold, The Loyalties of Fiduciary Law, in PHILOSOPHICAL Foundations OF FiduCIARY LAw (forthcoming 2014) (assessing whether the fiduciary duty of loyalty "has any essential content," and concluding that, "to a large degree, it does not"); Julian Velasco, How Many Fiduciary Duties Are There in Corporate Law?, 83 S. CAL. L. REV. 1231, 1257-77 (2010) (arguing that debates regarding the status of "good faith" vis-à-vis loyalty reduce to "semantics").

37. Companies Act § 178(1).

38. Id. (emphasis added). 
compensation to recompense the company for the harm caused to it by the director's breach." 39

The rationale for singling out the duty of loyalty as the sole "fiduciary duty" is straightforward. As Millett L.J. explains in the UK Court of Appeal's 1996 decision in Bristol and West Building Society v. Mothew ${ }^{40}$ :

The expression "fiduciary duty" is properly confined to those duties which are peculiar to fiduciaries and the breach of which attracts legal consequences differing from those consequent upon the breach of other duties. Unless the expression is so limited it is lacking in practical utility....

It is ... inappropriate to apply the expression to the obligation of a trustee or other fiduciary to use proper skill and care in the discharge of his duties. ${ }^{41}$

As to which duties "are special to fiduciaries" and thereby "attract those remedies which are peculiar to the equitable jurisdiction and are primarily restitutionary or restorative rather than compensatory," Millett concludes that the "distinguishing obligation of a fiduciary is the obligation of loyalty. The principal is entitled to the single-minded loyalty of his fiduciary." 42

In Mothew, Millett makes two key analytical moves. First, the descriptive term "fiduciary" is reserved for those duties "peculiar" to those occupying this status, rather than applying more broadly to all duties owed by someone in this position. ${ }^{43}$ Second, the resulting distinction between the fiduciary duty of loyalty and the nonfiduciary duty of care is mapped onto the availability of equitable remedies (available upon breach of the former but not the latter). This view regarding the core distinction between duties of care and loyalty - and the respective remedies available for their breach - has enjoyed wide adherence among British practitioners and academics alike. ${ }^{44}$ Moreover, Millett's analytical approach is

39. See DAviES, supra note 6 , at 495 ; see also Banerjee, supra note 6 , $\uparrow \uparrow$ 25.29-.41; Graham, supra note 6, ๆ $24.217-.218$.

40. [1998] Ch. 1 (Eng.).

41. Id. at 16 .

42. Id. at 18. In Mothew, declining to characterize the duty of care as "fiduciary" had the effect of requiring the plaintiff building society to establish causation in order to prevail in an action for damages against a solicitor who failed to report a borrower's second mortgage in connection with the building society's financing of a home purchase. See id. at 6-13.

43. Compare id. at 16 , with Velasco, supra note 36 , at 1277-305 (arguing that "distinguishing among fiduciary duties based on the paradigms for enforcement is most likely to lead to meaningful distinctions without risk of confusion," an analytical approach assuming that all duties of one occupying this status should be described as "fiduciary" in nature).

44. See, e.g., DaviES, supra note 6, at 495 (discussing the views expressed in Mothew and their implications); Banerjee, supra note 6, ๆ 25.21-.49 (same); 
largely consistent with those prevailing in Canada and Australia as well. ${ }^{45}$ In Mothew, Millett endorses views expressed in Canadian decisions that "to say that simple carelessness" amounts to breach of fiduciary duty "is a perversion of words," 46 and that "not every legal claim arising out of a relationship with fiduciary incidents will give rise to a claim for breach of fiduciary duty."47 Likewise, Millett endorses the view expressed in an Australian decision that "[t]he director's duty to exercise care and skill has nothing to do with any position of disadvantage or vulnerability on the part of the company. It is not a duty that stems from the requirements of trust and confidence imposed on a fiduciary." 48 Millett emphasizes that this core distinction between duties of care and loyalty "is not just a question of semantics. It goes to the very heart of the concept of breach of fiduciary duty and the availability of equitable remedies." 49

Graham, supra note 6, ๆๆ 24.217-.218 (same). Cf. Peter Birks, The Content of Fiduciary Obligation, 34 IsR. L. REv. 3, 35-36 (2000) (arguing that "care in the affairs of the beneficiary is the very heart of the trustee's obligation," but endorsing the outcome in Mothew and conceding that "[w]e might say that [care] is not especially fiduciary," relative to loyalty). But see Andrew Burrows, We Do This at Common Law but That in Equity, 22 OxFord J. LEGAL STUD. 1, 1 (2002) (advocating greater "fusion" of common law and equity, including with respect to "monetary remedies for civil wrongs").

45. See Banerjee, supra note 6, 925.46 (observing that Millett L.J. "noted that 'not every breach of duty by a fiduciary is a breach of fiduciary duty' and referred to similar observations in decisions from Canada and Australia").

46. Mothew, [1998] Ch. 1, at 16 (quoting Southin J. in Girardet v. Crease \& Co. (1987) 11 B.C.L.R. (2d) 361, 362).

47. Id. (quoting La Forest J. in LAC Minerals Ltd. v. Int'l Corona Res. Ltd. (1989) 61 D.L.R. (4th) 14, 28); see also Miller, supra note 6, at 256-59, 269-70, 281. But see id. at 281-85 (arguing that there is "a plausible case for recognition of a fiduciary duty of care" based on fiduciary-specific application of the care concept, but acknowledging that "significant inconsistencies and prevailing uncertainty in [Canadian] law make it somewhat artificial to speak of a fiduciary duty of care of general application").

48. Mothew, [1998] Ch. 1, at 17 (quoting Ipp J. in Permanent Bldg. Soc'y v. Wheeler (1994) 14 A.C.S.R. 109, 158). Definitions of the fiduciary relationship typically emphasize discretionary power to affect another's interests and a correlative vulnerability of the other party. See, e.g., Miller, supra note 6, at 262 (arguing that "a fiduciary relationship is one in which one party (the fiduciary) enjoys discretionary power over the significant practical interests of another (the beneficiary)" (emphasis omitted)).

49. Mothew, [1998] Ch. 1, at 17. It is interesting to note that the Companies Act 2006 includes no BJR-an omission that Paul Davies attributes to an expectation of the law commissions that courts would "be alive to the probability that they are better at dealing with conflicts of interest than with the assessment of business risks and to the desirability of avoiding the luxury of substituting the courts' hindsight for the directors' foresight." DAVIES, supra note 6, at 493-94; see also Charitable Corp. v. Sutton, 2 A.T.K. 400, 405, [1742] Eng. Rep. 642, 644 (Ch.) (remarking that "it is by no means just in a judge, after bad consequences have arisen from such executions of their power, to say that they foresaw at the time what must necessarily happen; and therefore were 
At this point, I must step back to remind the reader that, while the distinction drawn between duties of care and loyalty in the United Kingdom, Australia, and Canada offers the simplicity and analytical clarity that I argue Delaware law ought to pursue, one has to be very careful about advocating wholesale adoption of foreign regulatory models and legal structures, even among legal systems and business cultures as similar as those discussed here. Simply put, context matters-a point that I have explored elsewhere at some length ${ }^{50}$ and to which I return below.51 For present purposes, however, the modest threshold points are simply that a well-functioning corporate legal system need not conceptualize the duty of care as "fiduciary" in nature, and that distinguishing between duties of care and loyalty in this manner may offer discernible benefits through greater analytical clarity.

Indeed, the view outlined above has its proponents in the United States as well. William Gregory, for example, argues that the "duty of care is a negligence concept quite unlike the duty of loyalty"-in part by reference to Millett's opinion in Mothew-and concludes that equating them is "bad law and worse semantics." 52 More generally, Deborah DeMott argues that we ought to "distinguish between the fiduciary obligation as it applies to parties within corporations and other duties that may be owed to a corporation that are not distinctively fiduciary in character." "53 The director's duty of care, she explains, "is not distinctively fiduciary," as "many persons, by virtue of the law or their own contractual undertakings, owe duties of care to other persons with whom they have nonfiduciary relationships." 54 In this spirit, Gordon Smith-in developing his "critical resource" theory of fiduciary duty-clarifies that by "fiduciary duty," he means solely "a duty of loyalty." 55 The term "fiduciary duty," Smith explains, "connotes an obligation to refrain from self-interested behavior that constitutes a wrong to the beneficiary as a result of the fiduciary exercising discretion with respect to the beneficiary's critical resources." 56 The duty of care, by contrast, is not distinctly "fiduciary," insofar as "the intensity of the

guilty of a breach of trust"); Graham, supra note 6, ๆ 24.11 (observing that "our courts already traditionally decline to review commercial decisions made by directors in good faith").

50. See generally BRUNER, supra note 5.

51. See infra Part IV.

52. See William A. Gregory, The Fiduciary Duty of Care: A Perversion of Words, 38 AKRON L. REv. 181, 183-88 (2005) (discussing the Mothew decision and endorsing its analytical approach).

53. Deborah A. DeMott, Beyond Metaphor: An Analysis of Fiduciary Obligation, 1988 DUKE L.J. 879, 915.

54. Id.

55. D. Gordon Smith, The Critical Resource Theory of Fiduciary Duty, 55 VAND. L. REV. 1399, 1406-11 (2002).

56. Id. at 1407 . 
duty of care is not dependent on whether the person is acting as a fiduciary." 57

In this light, the relatively stark contrast drawn above between the approach taken in the United States, on the one hand, and that taken in the United Kingdom, Australia, and Canada, on the other, must be relaxed somewhat, because a more embracing view of the law of business organization in the United States reveals some variability in conceptual treatment of the duty of care. For example, while partnership law and corporate law style the duty of care a "fiduciary" duty, ${ }^{58}$ agency law does not. The Restatement (Third) of Agency provides that "[a]n agent has a fiduciary duty to act loyally for the principal's benefit in all matters connected with the agency relationship."59 This characterization of loyalty as the singular fiduciary duty is reinforced by contrast with the duty of care, which the Restatement (Third) describes as a "duty of performance."60 The Restatement (Third) provides that "an agent has a duty to the principal to act with the care, competence, and diligence normally exercised by agents in similar circumstances,"61 omitting the "fiduciary" descriptor. The conceptual distinction is underscored, then, in explanatory materials; one comment notes that the "general fiduciary principle complements and facilitates an agent's compliance with duties of performance," 62 while a reporter's note observes of the "duties of care, competence, and diligence" that these "are duties of performance, not duties of loyalty." 63

The upshot is that, while the duty of care is widely described as a "fiduciary" duty in the United States, U.S. business organization law is in fact not entirely consistent regarding its status, and U.S. legal scholars continue to hold differing views on the matter. Put differently, characterizing the director's duty of care as a "fiduciary" duty is a choice and would appear to be no more inevitable in the United States than elsewhere.

57. Id. at 1406-07, 1409. Cf. TAMAR FrankEL, FidUCIARY LAW 169-70 (2011) (characterizing enforcement of the duty of care as "weaker" and "less strict" than enforcement of the duty of loyalty); DeMott, supra note 53, at 921-23 (emphasizing the freedom to exculpate director liability for care breaches but not loyalty breaches).

58. See, e.g., Stone v. Ritter, 911 A.2d 362, 370 (Del. 2006) (clarifying that "the duties of care and loyalty," unlike "good faith," are fiduciary duties); REVISED UNIF. P'SHIP ACT $\S 404$ (a) (1997) ("The only fiduciary duties a partner owes to the partnership and the other partners are the duty of loyalty and the duty of care set forth in subsections (b) and (c).").

59. RESTATEMENT (THIRD) OF AGENCY $\$ 8.01$ (2006) (emphasis added).

60. Id. $\S 8.08$.

61. Id. (emphasis added).

62. Id. $\$ 8.01 \mathrm{cmt}$. b.

63. Id. $\S 8.08$ Reporter's note b. The emphasis placed on this distinction presumably reflects Deborah DeMott's influence as Reporter. See Deborah A. DeMott, DUKE LAW, http://aw.duke.edu/fac/demott (last visited Sept. 18, 2013) (noting that DeMott served in this capacity); see also DeMott, supra note 53. 


\section{CARE, LOYALTY, AND THE BJR}

How has the choice to conceptualize the director's duty of care as a "fiduciary" duty affected the emergence and evolution of Delaware's doctrinal structure? The answer appears to be: quite substantially.

A "fiduciary duty of care" was effectively a prerequisite to the events described above, facilitating the conflation of care and loyalty brought about by Delaware's oddly phrased BJR.64 Until the 1980s, it was widely accepted that breach of the directors' duty of care in the exercise of business judgment simply could not give rise to monetary damages, ${ }^{65}$ and, to the degree any practical utility could be ascribed to the articulation of a "business judgment rule," it served as a convenient shorthand for this principle. In Shlensky $v$. Wrigley, ${ }^{66}$ for example, the Appellate Court of Illinois in 1968 famously refused to second-guess a business decision "properly before directors" (i.e., a decision not to install lights and play night games at Wrigley Field) short of a showing of "fraud, illegality or conflict of interest in their making of that decision."67

Delaware, for its part, has long framed the BJR as a "presumption," but early formulations did so in a manner suggesting that only disloyalty could give rise to monetary damages. For example, in 1928, the Court of Chancery wrote the following:

The directors are chosen to pass upon such questions [of business policy] and their judgment unless shown to be tainted with fraud is accepted as final. The judgment of the directors of corporations enjoys the benefit of a presumption that it was formed in good faith and was designed to promote the best interests of the corporation they serve. 68

By the mid-1980s, as noted above, the perception of the marketplace remained that monetary liability could not be imposed upon a director short of disloyalty, ${ }^{69}$ although in retrospect we can see that by this time, the formulation of Delaware's BJR had changed in subtle but important respects. Again, in Aronson, the Delaware Supreme Court characterized the BJR as "a presumption that in making a business decision the directors of a corporation

64. Recall, by way of contrast, that the United Kingdom rejected adoption of a formal BJR in its company law reform efforts in the 1990s and 2000s, but that this appears to have been motivated by a long-established posture of nonreview of good faith business decisions in the British courts-an informal position resembling that formalized historically through the BJR in the United States. See supra note 49 and accompanying text.

65. See Bruner, supra note 1, at 1139-44.

66. 237 N.E.2d 776 (Ill. App. Ct. 1968).

67. Id. at 780 .

68. Davis v. Louisville Gas \& Elec. Co., 142 A. 654, 659 (Del. Ch. 1928), quoted in Shlensky, 237 N.E.2d at 779.

69. See Bruner, supra note 1 , at 1139-44. 
acted on an informed basis, in good faith and in the honest belief that the action taken was in the best interests of the company."70

Notwithstanding the formal similarity-each iteration styling the BJR a "presumption" in the directors' favor-the latter differs in expressly referring to matters implicating both care and loyalty. As opposed to articulating the presumption in a manner suggesting that monetary liability could be imposed only upon a showing of disloyalty, as the earlier formulation had, the Aronson formulation simultaneously suggested that the BJR could be overcome solely by reference to the quality of board decision making, and-just as troublingly-tended to suggest that the duties of care and loyalty were themselves intrinsically linked with one another in some deep manner embodied in, or subsumed by, the BJR itself.

The latent potential for the Aronson formulation to permit damages solely by reference to the quality of board decision making would, as discussed above, materialize in Van Gorkom, ${ }^{71}$ and likewise the latent potential for this strange BJR formulation to give rise to confusion regarding the nature of care and loyalty dutiesand their relationship to one another-would ultimately materialize in the Cede \& Co. v. Technicolor, Inc. ${ }^{72}$ saga. In Cede, the Delaware Supreme Court rejected the Chancellor's ruling that plaintiffs seeking damages for breach of the duty of care would have to establish not only a breach of duty but also that the breach proximately caused a loss. ${ }^{73}$ The Chancellor's approach, applying traditional negligence-based analysis derived from long-standing "tort principles,"74 was characterized by the Delaware Supreme Court as "rewriting the Delaware business judgment rule's requirement of due care." 75 Carrying the latent potential for confusion embedded in the Aronson formulation to its logical extreme, the Cede court fully subsumed the duties of care and loyalty within the BJR, depicting the BJR itself as the primary embodiment of the rigors of "fiduciary" status, with care and loyalty alike relegated to secondary status as mere reflections of the BJR. The court lumped together "good faith, loyalty [and] due care" as means of overcoming the BJR, ${ }^{76}$ clearly conceptualizing these duties as expressions of a fundamental and singular fiduciary concept

70. Aronson v. Lewis, 473 A.2d 805, 812 (Del. 1984) (emphasis added), overruled on other grounds by Brehm v. Eisner, 746 A.2d 244 (Del. 2000).

71. See Smith v. Van Gorkom, 488 A.2d 858, 874-93 (Del. 1985), overruled on other grounds by Gantler v. Stephens, 965 A.2d 695 (Del. 2009).

72. 634 A.2d 345 (Del. 1993), modified on reh'g, 636 A.2d 956; see also DALE A. Oesterle, The LAW OF Mergers AND ACQUisitions 353-54 (4th ed. 2012) (describing "the many bad opinions in the horrific [Cede] litigation," which ultimately became "one of the longest trials in Delaware court history").

73. Cede, 634 A.2d at 366-71.

74. Id. at 369 .

75. Id. at 371 .

76. See id. at 361 . 
embodied more holistically by the BJR itself. ${ }^{77}$ The court explained that "[d]uty of care and duty of loyalty are the traditional hallmarks of a fiduciary who endeavors to act in the service of a corporation and its stockholders," and characterized the duty of care itself as a mere "element of the business judgment rule" embodied by the Aronson requirement that the board inform itself. 78 In this light, the court characterized the Chancellor's requirement of proximate cause as an unprecedented hurdle to rebuttal of the BJR, ${ }^{79}$ arriving at the remarkable conclusion that breach of the duty of care-with no showing of resulting injury-rebuts the BJR and "requires the directors to prove that the transaction was entirely fair," the standard typically applied in the duty of loyalty context. 80 The court then went on to "emphasize" the consequence of this move with respect to remedies-the availability of "rescissory damages" (or any other form of equitable or monetary relief deemed "appropriate" by the Chancellor). ${ }^{81}$

As Lyman Johnson would observe of this holding, "none of the authority cited ... supports the novel proposition that, in a duty of care case, a director must carry the burden of proving the entire fairness of a challenged transaction"82-a burden that was, ironically enough, found to have been met in the end. ${ }^{83}$ Johnson

77. Cf. Gregory, supra note 52, at 190 ("The astonishing innovation of the Delaware Supreme Court [in Cede] is to destroy the distinction between intentional conduct and negligent conduct.").

78. See Cede, 634 A.2d at 367 ; see also Model Bus. Corp. Act $\$ \S 8.30(\mathrm{~b})$, 8.31 (a)(2)(ii)(B) (2010) (tending to reduce the duty of care to a duty to inform oneself via the BJR); Johnson, supra note 10, at 794-95 (observing that this approach "diminishes" the duty of care by "making that core concept coextensive with the informedness element found in Aronson's flawed (but oftcited) formulation" of the BJR).

As Lyman Johnson observes, the fact that Delaware's BJR predated any clear articulation of a director's duty of care set the stage for this move in Cede. Lyman Johnson, Unsettledness in Delaware Corporate Law: Business Judgment Rule, Corporate Purpose, 38 DEL. J. CoRP. L. (forthcoming 2013) (manuscript at 8-9), available at http://papers.ssrn.com/sol3/papers.cfm ?abstract_id=2277645; see also sources cited supra note 10 . Note, however, that it remains coherent to conceptualize the duty of care as analytically prior to the BJR today. See Johnson, supra (manuscript at 24) (emphasizing that the BJR is better conceptualized as an "an aspect of duty of care review"); id. (manuscript at 27) (suggesting that the BJR presumption "presupposes that directors are behaving carefully and loyally, without expressly stating it just that way").

79. See Cede, 634 A.2d at 368-69.

80. Id. at $370-71$.

81. Id. at 371 .

82. See Johnson, supra note 10, at 799-801.

83. See Cinerama, Inc. v. Technicolor, Inc., 663 A.2d 1156, 1179-80 (Del. 1995) (finding that, on remand, the "Court of Chancery meticulously considered and weighed each aspect of fair dealing and fair price," and that the record supported the Court of Chancery's conclusion that the transaction was entirely fair, representing "the highest price reasonably available" in the merger at 
rightly observes that "the business judgment rule is ill-equipped to serve as the umbrella concept for analytically linking director duties ... with standards of judicial review," being a "narrower" concept than the duties themselves. ${ }^{84}$ Indeed, as discussed above, the duty of loyalty and the BJR, properly understood, quite literally have nothing to do with one another. In Cede, the Delaware Supreme Court suggested that the duties of care and loyalty alike represent procedural means of "rebut[ting] the presumption that the directors have acted in the best interests of the shareholders," and this unity-born of their twin status as "the traditional hallmarks of a fiduciary"-forms the conceptual foundation for the court's conclusion that breach of either duty should trigger the same procedural, analytical, and remedial consequences. ${ }^{85}$ But the duty of loyalty is in fact quite awkwardly styled as a means of overcoming the BJR; it would be more historically accurate and conceptually coherent to say that the BJR is simply inapposite to loyalty problems in much the same way that the BJR is inapposite to cases not involving an exercise of business judgment. In such cases, the BJR has no application and straightforwardly provides no protection. ${ }^{86}$ Regardless, however, the fundamental flaw motivating the Cede analysis persists in Delaware and elsewhere. 87

In order to perceive more clearly the role of the "fiduciary" label in facilitating the emergence of this doctrinal structure, it may help to pause at this point to approach the matter through a counterfactual: Could the Delaware Supreme Court conceivably have reached the conclusion it did in Cede without having styled care a "fiduciary" duty? It is difficult to imagine how the court could

issue). Note that $\S 102(\mathrm{~b})(7)$ could not protect the Technicolor directors from this mess because the operative events occurred before $\S 102(b)(7)$ was enacted. See id. at 1165 n.17.

84. Johnson, supra note 10, at 802-03 ("Both the duty of care and the duty of loyalty govern corporate directors whether or not directors make business decisions, while the business judgment rule applies only when directors do make such decisions.").

85. See Cede, 634 A.2d at $367,371$.

86. Compare Gagliardi v. TriFoods Int'l, Inc., 683 A.2d 1049, 1051 (Del. Ch. 1996) ("The business outcome of an investment project that is unaffected by director self-interest or bad faith cannot itself be an occasion for director liability. That is the hard core of the business judgment doctrine."), with Aronson v. Lewis, 473 A.2d 805, 812-13 (Del. 1984) (explaining that the BJR applies only to directors' actions, not "where directors have either abdicated their functions, or absent a conscious decision, failed to act"), overruled on other grounds by Brehm v. Eisner, 746 A.2d 244 (Del. 2000). See also Velasco, supra note 36 , at 1306, 1314-17 (observing that before Cede, the BJR applied to care claims while the entire fairness standard applied to loyalty claims, and advocating that Delaware abandon the Cede approach and return to the "traditional model").

87. See, e.g., PRINCIPles of CoRporate Governance: ANAlysis AND RECOMMENDATIONS $\S 4.01$ (1994) (similarly conflating care and loyalty as "a duty to the corporation," in the singular). 
have done so. Critically, each step of the court's analysis rests fundamentally on this conceptual foundation: (1) conflating duties of care and loyalty as "the traditional hallmarks of a fiduciary who endeavors to act in the service of a corporation and its stockholders";88 (2) restyling the BJR itself as the embodiment of that singular fiduciary concept, with care and loyalty breaches alike reduced to means of overcoming the BJR; and (3) concluding that, because care and loyalty breaches are similarly just means of overcoming the BJR's presumption of fiduciary rectitude, the procedural consequences and remedies in each instance must be the same. Not one of these steps could logically be taken without first conceptualizing care as a "fiduciary" duty, rendering it difficult to imagine that Delaware's present doctrinal structure could have arisen had care not been conceptualized this way.

From a pragmatic perspective, the fundamental problem with Delaware's conflation of care and loyalty is that it impedes recognition of the fact that these duties address different problems with different moral valences, calling for different enforcement regimes. Historically, the duty of loyalty has been more aggressively enforced in order to deter conflicts of interest, a policy premised on the implicit, and quite valid, empirical assumption that the actor in question will generally be well positioned to minimize his or her own liability exposure by conscientiously policing the nature of his or her own undertakings. In the agency context, for example, in Tarnowski v. Resop ${ }^{89}$ the Supreme Court of Minnesota justified disgorgement of secret profits-regardless of injury-with the observation that "[a]ctual injury is not the principle the law proceeds on, in holding such transactions void. Fidelity in the agent is what is aimed at, and, as a means of securing it, the law will not permit him to place himself in a position in which he may be tempted by his own private interests." 90 Similarly, in the partnership context, then-Chief Judge of the New York Court of Appeals Benjamin Cardozo famously explained in Meinhard $v$. Salmon 91 that a joint venturer owed his "coadventurer" a duty of disclosure regarding a new opportunity arising from the venture and that the "price of its denial" was that the new opportunity would be held in trust "at the option and for the benefit of the one whom he excluded"-regardless of the likelihood that such disclosure "would have been of little value even if seasonably offered."92 Similarly, in Guth v. Loft, Inc., ${ }^{93}$ the Delaware Supreme Court explained that

88. Cede, 634 A.2d at 367.

89. 51 N.W.2d 801 (Minn. 1952).

90. Id. at 803 (emphasis added) (quoting Lum v. McEwen, 57 N.W. 662, 663

(Minn. 1894)).

91. 164 N.E. 545 (N.Y. 1928).

92. Id. at 547 (emphasis added).

93. 5 A.2d 503 (Del. 1939). 
"[c]orporate officers and directors are not permitted to use their position of trust and confidence to further their private interests," standing "in a fiduciary relation to the corporation and its stockholders." 94 As a consequence of this duty of loyalty, the court explained that

[i]f an officer or director of a corporation, in violation of his duty as such, acquires gain or advantage for himself, the law charges the interest so acquired with a trust for the benefit of the corporation, at its election, while it denies to the betrayer all benefit and profit. The rule, inveterate and uncompromising in its rigidity, does not rest upon the narrow ground of injury or damage to the corporation resulting from a betrayal of confidence, but upon a broader foundation of a wise public policy that, for the purpose of removing all temptation, extinguishes all possibility of profit flowing from a breach of the confidence imposed by the fiduciary relation..$^{95}$

In each case, a clear policy of deterrence-predicated upon an empirical assumption that scrupulous fiduciaries could realistically avoid such difficulties and a correlative moral stigma associated with breach-facilitated more aggressive enforcement of the duty of loyalty. ${ }^{96}$ As Douglas Branson has expressed it, "the duty of loyalty deals with purposeful conduct of a venal, opportunistic sort," such that in "the common law hierarchy of fault, duty of loyalty violations rank high." 97

94. Id. at 510.

95. Id. (emphasis added).

96. Cf. Paul B. Miller, Justifying Fiduciary Remedies, 63 U. TORONTO L.J. (forthcoming 2013) (manuscript at 46-63), available at http://ssrn.com/abstract $=2167883$ (characterizing fiduciary power as "a means" belonging to the beneficiary, giving rise to an "implied entitlement" to gains from the exercise of that power, such that disgorgement "restores to the beneficiary gains to which she was entitled"); Smith, supra note 55, at 1494-95 (arguing that the "beneficiary becomes entitled to the fiduciary's loyalty when the fiduciary exercises discretion with respect to the beneficiary's critical resources," and that remedies vindicating "the beneficiary's entitlement may in some cases exceed the beneficiary's actual loss"); Paul B. Miller, The Fiduciary Relationship 10-15 (2013) (unpublished manuscript) (on file with author) (arguing that "fiduciary power is distinguishable from other varieties of power by virtue of the fact that it is a form of authority ... derived from the legal personality of another").

97. Branson, supra note 17 , at 384 . While corporate statutes may insulate interested director transactions from heightened scrutiny when approved by disinterested parties or otherwise shown to be "fair"-for example, DEL. CODE ANN. tit. 8, § 144 (2012) - this does not reflect tolerance of self-dealing so much as pragmatic recognition that insiders may occasionally offer their companies better terms than outsiders would. Prohibiting interested director transactions outright would come at "the cost of deterring some mutually beneficial transactions, as when directors are more confident about a corporation's prospects than are banks or outside investors." WILLIAM T. ALLEN ET AL., COMMENTARIES AND CASES ON THE LAW OF Business ORganization 300 (2nd ed. 
In duty of care cases, on the other hand, we have historically seen exactly the opposite-weak enforcement premised on the express, and equally valid, empirical assumption that the actor in question could not manage his or her own liability exposure in so straightforward a manner, simultaneously diminishing the moral stigma associated with breach and raising the prospect of detrimental risk aversion. Then-Chancellor Allen-presumably responding to the bewildering doctrinal structure created by the Delaware Supreme Court in the Cede litigation ${ }^{98}$ - strongly emphasized these dynamics in two subsequent opinions issued just a year after the Cede litigation concluded. In Gagliardi v. TriFoods International, Inc.99-a 1996 opinion citing neither Aronson's formulation of the BJR nor the framework established in the Cede litigation-Allen endeavored to resurrect the stronger historical articulation of the BJR to the effect that the "business outcome of an investment project that is unaffected by director self-interest or bad faith cannot itself be an occasion for director liability." 100 In support of this approach, he argued that "[ $t]$ he rule could rationally be no different" because if corporate directors

were to be found liable for a corporate loss from a risky project on the ground that the investment was too risky (foolishly risky! stupidly risky! egregiously risky!-you supply the adverb), their liability would be joint and several for the whole loss (with I suppose a right of contribution). Given the scale of operation of modern public corporations, this stupefying disjunction between risk and reward for corporate directors threatens undesirable effects. Given this disjunction, only a very small probability of director liability based on "negligence", "inattention", "waste", etc., could induce a board to avoid authorizing risky investment projects to any extent!101

The BJR, in Allen's formulation, responds to this threat of risk aversion, insulating directors and shareholders alike from "the uneconomic consequences that the presence of such second-guessing risk would have on director action and shareholder wealth."102

2007). Consequently, the "evolution of fiduciary law of director self-dealing mirrors the interplay among these competing goals." Id.

98. Note that it was Allen's effort to require proof of injury that the Delaware Supreme Court rejected in this litigation. See Cinerama, Inc. v. Technicolor, Inc., No. CV-8358, 1991 WL 111134, at *582 (Del. Ch. June 24, 1991), aff'd in part, rev'd in part, Cede \& Co. v. Technicolor, Inc., 634 A.2d 345 (Del. 1993).

99. 683 A.2d 1049 (Del. Ch. 1996).

100. Id. at 1051 .

101. Id. at 1052 .

102. Id.; see also StePhen M. BAINBRIDGe, CoRPorATE LAW 128 ( $2 \mathrm{~d}$ ed. 2009) (observing that rescissory damages in a duty of care case "would have the effect of ordering the defendant directors to return a benefit that they never received" 
In his In re Caremark Int'l Inc. Derivative Litigation opinion later that year, Allen reiterated this argument and emphasized the resulting analytical and moral distinction between care and loyalty breaches. ${ }^{103}$ Allen observed that if directors "are to be adjudged personally liable for losses on the basis of a substantive judgment based upon what persons of ordinary or average judgment and average risk assessment talent regard as 'prudent' 'sensible' or even 'rational', such persons will have a strong incentive at the margin to authorize less risky investment projects."104 In this case, however, he carried the analysis a step further, adding that "one wonders on what moral basis might shareholders attack a good faith business decision of a director as 'unreasonable' or 'irrational."' $105 \mathrm{He}$ continues, quoting from Barnes $v$. Andrews ${ }^{106}$-the case upon which Allen had based the approach to care analysis rejected by the Delaware Supreme Court in the Cede litigation-where Judge Learned Hand stated that directors "are the general advisors of the business and if they faithfully give such ability as they have to their charge, it would not be lawful to hold them liable."107 While sharply contrasting with the approach endorsed by the Delaware Supreme Court in the Cede litigation, Allen's 1996 opinions in Gagliardi and Caremark nicely express the logic of the historical approach to the BJR as well as the analytical and moral distinction leading courts to adopt very different approaches to care and loyalty breaches. ${ }^{108}$

and further "threaten to be so astronomical as to substantially chill the decisionmaking process").

103. See generally In re Caremark Int'l Inc. Derivative Litig., 698 A.2d 959 (Del. Ch. 1996).

104. Id. at $967-68$ n. 16 .

105. Id. at 968 .

106. 298 F. 614 (S.D.N.Y. 1924).

107. In re Caremark, 698 A.2d at 968 (emphasis added) (quoting Barnes, 298 F. at 618).

108. See also FRANKEL, supra note 57, at 169-73 (providing a similar explanation of why enforcement of the duty of care has historically been "weaker" and "less strict" than enforcement of the duty of loyalty); Branson, supra note 17, at 384 n.42 ("Ironically, with duty of care claims the fault may be small yet the damages may be great, out of all proportion to the fault involved.... In duty of loyalty cases, the fault may be regarded as severe but the damages for which the director is held accountable may be relatively limited ...."); cf. Bane v. Ferguson, 890 F.2d 11, 14 (7th Cir. 1989) (indicating that the BJR applies in the partnership context "just as it would" in the corporation context); REVISED UNIF. P'SHIP ACT § 404(c) (1997) (limiting the duty of care in the partnership context to "refraining from engaging in grossly negligent or reckless conduct, intentional misconduct, or a knowing violation of law"). While there are, to be sure, circumstances where courts have embraced more robust enforcement of the duty of care, this has generally been limited to banking cases, reflecting deep concerns regarding the social costs of excessive risk taking in this unique context. See Christopher M. Bruner, Conceptions of Corporate Purpose in Post-Crisis Financial Firms, 36 SEaTtle U. L. Rev. 527, 538-40, 545-46 (2013). 
While analysis of oversight failures through the conceptual lens of "good faith" might seem to be in tension with the binary enforcement structure described above-insofar as good faith itself is conceptualized as a component of the duty of loyalty, yet application of the rigorous Caremark standard effectively undercuts enforcement in a manner resembling the traditional approach to the duty of care109_the tension is in fact illusory. As I have explored in prior work, good faith is fundamentally about state of mind-the quality of a director's intentions vis-à-vis the company. ${ }^{110}$ This is the core of the argument for conceptualizing good faith as a component of the duty of loyalty. ${ }^{111}$ The practical problem, however, is that the quality of intentions can be exceedingly difficult to judge in oversight cases where (by hypothesis) the plaintiffs' allegations involve failures to act. In essence, application of the Caremark standard to oversight cases has the effect of permitting good faith to be conceptualized (properly, in my view) as a component of loyalty while limiting the availability of associated remedies to those circumstances sufficiently egregious to permit an inference of bad intentions vis-à-vis the company-specifically, circumstances where there is total board failure to engage in oversight. ${ }^{112}$

Having observed that conflation of the duties of care and loyalty as reflections of a singular, underlying "fiduciary" concept has resulted in a tendency toward overenforcement of the corporate director's duty of care, one might naturally ask whether such conflation has similarly resulted in a tendency toward underenforcement of the director's duty of loyalty. Indeed, looking beyond corporate law, there is ample evidence of the erosion of loyalty in the law of business organization more generally. The

109. Note that oversight cases have traditionally been treated as duty of care cases in other jurisdictions and were so treated in Delaware itself until relatively recently. See, e.g., Francis v. United Jersey Bank, 432 A.2d 814, 82426 (N.J. 1981); In re Caremark, 698 A.2d at 971. Only with the Delaware Supreme Court's holding in Stone $v$. Ritter would it be firmly established that oversight cases-via the good faith inquiry undertaken in Caremark-would be treated by Delaware courts as implicating the duty of loyalty. See supra notes 18-19 and accompanying text.

110. See generally Bruner, supra note 1; see also Bruner, supra note 19.

111. See Bruner, supra note 1 , at 1137.

112. See id. at 1180-82, 1184-86; Bruner, supra note 19, at 589-91. Julian Velasco has explored the intriguing possibility that treating good faith and "traditional loyalty" as reflections of a single duty might create pressure toward a single standard of review, such that "good faith would be overenforced and loyalty would be underenforced"-a concern resembling that raised in this Essay regarding conflation of care and loyalty as reflections of a singular, underlying "fiduciary" concept. See Velasco, supra note 36, at 1293-94. While Velasco's concern is well taken, to date there would appear to be little evidence of such pressure-presumably because the Caremark standard has so decisively circumscribed the substantive scope of good faith claims. See, e.g., Bruner, supra note 19 , at 589-91. 
Revised Uniform Partnership Act, for example, limits the scope of the duty of loyalty 113 and then expressly permits further carve-outs in the partnership agreement to the extent "not manifestly unreasonable."114 The Revised Uniform Limited Liability Company Act similarly permits contractual limitation of the duty of loyalty through the operating agreement, 115 while Delaware goes even further, permitting "fiduciary duties" to be "expanded or restricted or eliminated by provisions in the limited liability company agreement."116 Naturally, then, one wonders what fate awaits the corporate director's duty of loyalty and how inhabiting the singular "fiduciary" vessel with the duty of care may affect its fortunes.

This broader trend toward relaxing the duty of loyalty reflects, in substantial part, the ascendance of the "law and economics" movement. Specifically, the "contractarian" approach to business firms effectively aims (as the moniker implies) to collapse the entirety of the law of business organization into contract, styling duties of care and loyalty alike as mere gap fillers to be employed sparingly where contracts remain imperfectly specified due to the complexity of the firm's undertakings. Frank Easterbrook and Daniel Fischel, in their 1991 book The Economic Structure of Corporate Law, assert that "[i]f contracts can be written in enough detail, there is no need for 'fiduciary' duties as well."117 On this view, the "fiduciary principle" constitutes "an alternative to elaborate promises and extra monitoring." 118 This, of course, is a long way from the robust duty of loyalty contemplated historically in the cases cited above.119 Loyalty, on the contractarian view, amounts to little more than a "default" rule that the parties ought to be free to "waive"120_and the degree to which this relegation"121 has

113. Revised UNIF. P'SHIP ACT $\$ 404$ (b)(1) (1997) (limiting the partner's duty of loyalty to accounting for benefits received through the partnership's business or property, refraining from "dealing with the partnership," and refraining from "competing with the partnership").

114. Id. § 103(b)(3)(i); see also id. § 103(b)(4) (similarly permitting the parties to "reduce the duty of care," but not "unreasonably").

115. See Revised UNIF. LTD. LIAB. Co. ACT $\S \S 110(d)(1), 409(b)$ (2006) (permitting parties to "restrict or eliminate" enumerated aspects of the duty of loyalty if "not manifestly unreasonable"); see also id. § 110(d)(3) (similarly permitting the parties to "alter the duty of care").

116. DEL. CODE ANN. tit. 6, § 18-1101(c) (2012) (emphasis added).

117. Frank H. Easterbrook \& Daniel R. Fischel, The Economic STRUCTURE OF CORPORATE LAW 90 (1991).

118. Id. at 92 .

119. See supra notes 89-95 and accompanying text.

120. See, e.g., Larry E. Ribstein, Fiduciary Duty Contracts in Unincorporated Firms, 54 WASH. \& LEE L. REV. 537, 546-50 (1997).

121. For arguments more broadly challenging the equation of fiduciary law with contract law, see FRANKEL, supra note 57, at 229-39; DeMott, supra note 53, at 885-908; and Smith, supra note 55, at 1428-29. 
been premised on a singular "fiduciary" concept has not received sufficient attention.

While the duty of loyalty has, to date, remained quite a bit more robust in corporate law than it has in other areas, ${ }^{122}$ efforts to render the corporate duty of loyalty waiveable have been advanced on multiple occasions since the 1980s, and, tellingly, these efforts have expressly aimed to blur the distinction between care and loyalty as a means of deflating the heightened moral valence historically associated with loyalty breaches. For example, Douglas Branson recounts that at a May 1986 meeting of the American Law Institute ("ALI"), Frank Easterbrook argued that a draft provision of the ALI's Principles of Corporate Governance should be interpreted to permit a corporation to "amend its articles of incorporation to exempt that corporation's directors and officers from all or part of the common law fiduciary duty of loyalty."123 As Branson (writing in 1988) would observe, this effort to render the corporate duty of loyalty waiveable arose around the same time that exculpation statutes began to sweep the country, and the contractarian strategy was effectively to blur the conceptual distinction between care and loyalty in order to extend to the latter duty the contractual flexibility newly afforded in the case of the former. ${ }^{124}$ Notwithstanding the "sharp differences in treatment of the two duties" historically, "Chicago School law and economics scholars . . . discern a difference in degree but not in quality between conduct the duty of care regulates and conduct the duty of loyalty governs. In economic terms, the distinction between fiduciary duties is thought to be strained." 125 Branson then identifies the strategic opportunity that the rise of exculpation statutes presented to contractarians: "A majority of states' corporation laws permit a corporation, or a majority of its shareholders, to dispense with the liability of corporate officials to the corporation for violations of the duty of care. Under the economic analysis, then, the law also should permit opting out of applicability of the duty of loyalty." 126

While the corporate director's duty of loyalty has, to date, withstood the contractarian "assault" (as Branson described it in the late 1980s), ${ }^{127}$ contractarians have continued to attack the analytical and moral distinctions historically drawn between care and loyalty in an effort to undermine aggressive enforcement of the duty of loyalty-an effort involving conflation of the two duties through a

122. See, e.g., DEL. CODE ANN. tit. 8, § 102(b)(7) (2012) (barring exculpation of damages for loyalty breaches).

123. See Branson, supra note 17, at 378-80 (paraphrasing Easterbrook).

Branson himself attended the meeting in question. See id. at 378 n.14.

124. See id. at $380-85$.

125. Id. at 384 .

126. Id. at 383-84.

127. See, e.g., id. at $380-85$. 
singular "fiduciary" concept. Easterbrook and Fischel, writing in 1991, support their argument for fully waiveable duties of care and loyalty in part by reference to the BJR, which broadly "reflects limits on the use of liability rules to assure contractual performance."128 Lest the reader think that this argument might apply with particular force to the duty of care, however, they emphasize that, "[u]ltimately, ... there is no sharp line between the duty of care and the duty of loyalty.... Both are agency costs, conflicts of interest in the economic sense, that reduce shareholders' wealth."129 While they acknowledge that there may, as a practical matter, be "differential payoffs from breach and policing," the distinction is not a categorical one.130 "The duty of loyalty supplements market penalties for breach," they conclude, "in those situations where the market penalties themselves might be insufficient."131 Then, in a 1993 article titled Contract and Fiduciary Duty, Easterbrook and Fischel take direct aim at the moral distinction historically drawn between duties of loyalty and care and further argue that "fiduciary" relations are in fact not morally distinguishable from garden-variety contractual relations. ${ }^{132}$ "The duty of loyalty," they explain, merely "replaces detailed contractual terms," and the "usual economic assessments of contractual terms and remedies then apply." 133 The straightforward consequence is that "[f]iduciary duties are not special duties; they have no moral footing; they are the same sort of obligations, derived and enforced in the same way, as other contractual undertakings." 134

In sum, the effort to conflate care and loyalty concepts undergirds both the specific contractarian argument that capacity to "opt out" of the duty of care through exculpation ${ }^{135}$ ought to be extended to the duty of loyalty, as well as the more general contractarian argument that "fiduciary" relations are not categorically distinguishable from arm's-length contractual relations. As noted above, the duty of loyalty has retained greater vitality in Delaware corporate law to date, ${ }^{136}$ and the Delaware

128. EASTERBROOK \& Fischel, supra note 117, at 94 .

129. Id. at 103.

130. Id.

131. Id. (emphasis added).

132. Frank H. Easterbrook \& Daniel R. Fischel, Contract and Fiduciary Duty, 36 J.L. \& EcON. 425, 425-28 (1993).

133. Id. at 427 .

134. Id.; see also id. at 438.

135. See, e.g., Branson, supra note 17 , at 380-81 (describing exculpation statutes as permitting corporations to "opt out" of the duty of care); Velasco, supra note 36, at 1256 (describing exculpation statutes as permitting corporations to "contract around the duty of care if they choose").

136. See DEL. CODE ANN. tit. 8, $\S 102(b)(7)$ (2012) (barring exculpation of damages for loyalty breaches). 
Supreme Court has shown only limited receptivity to the contractarian view of fiduciary duty in the corporate context. 137 In light of the foregoing efforts, however, there is reason to believe that permitting conflation of care and loyalty could, in the future, contribute to underenforcement of the corporate director's duty of loyalty in much the same manner that it has already contributed to periodic overenforcement of the director's duty of care.

\section{IV. "FidUCIARY" DUTY ANALYSIS AND MONETARY DAMAGES}

In stark contrast with other common law jurisdictions-where a clearer analytical distinction between care and loyalty has helped to preserve distinct enforcement regimes more appropriate to the differing practical problems and degrees of moral culpability encountered in each respective domain-in Delaware, the concepts of care and loyalty have been conflated in a manner that has rendered the duty of care framework incoherent and unworkable. The result has been a periodic tendency toward overenforcement, while at the same time creating traps for the unwary, inviting wasteful litigation, and preserving potential for further pointless swings of the pendulum. At the same time, there is reason to believe that conflating care and loyalty could facilitate erosion of the duty of loyalty in the future by obscuring the practical and moral case for aggressive enforcement.

To reiterate a point well worthy of emphasis, I do not advocate literal adoption of any particular regime or approach prevailing elsewhere; the embeddedness of these doctrines in distinct legal systems, business cultures, and political economies would render such a project a fraught undertaking indeed. ${ }^{138}$ The contrast drawn here does, however, help to illuminate the role played by the conflation of care and loyalty duties in bringing about Delaware's muddled doctrinal structure, as well as the degree of analytical clarity sacrificed in conceptualizing these duties as Delaware has.

The statutory damages rule that I urge the Delaware General Assembly to adopt would go a long way toward achieving a more coherent and workable enforcement regime for the duty of care and

137. In its 1993 Nixon v. Blackwell decision, the Delaware Supreme Court declined to provide "judicially-created rules to 'protect' minority stockholders of closely held Delaware corporations." 626 A.2d 1366, 1379 (Del. 1993). Specifically, the court rejected the notion that minority shareholders were entitled to equal liquidity, quoting Easterbrook and Fischel for the proposition that "[t]o say that fiduciary principles require equal treatment is to beg the question whether investors would contract for equal or even equivalent treatment." Id. at 1377 (quoting EASTERBROOK \& FISCHEL, supra note 117, at 110). The court urged would-be minority shareholders in closely held corporations to exhibit greater foresight, explaining that "tools of good corporate practice are designed to give a purchasing minority stockholder the opportunity to bargain for protection before parting with consideration." Id. at 1380 .

138. See BRUNER, supra note 5, at 13-27, 287-92. 
the duty of loyalty alike. By expressly permitting the imposition of monetary damages for a director's loyalty breaches while foreclosing such damages for care breaches, 139 the periodic tendency toward overenforcement of care and the nascent potential for underenforcement of loyalty would be arrested at the same time. Clarifying that damages for breach of a director's duty of care are simply unavailable would effectively eliminate the need for a BJR (at least with respect to monetary liability) ${ }^{140}$ as well as the associated temptation to conflate duties of care and loyalty and the consequences of their breach. At the same time, a statutory provision emphasizing their distinctiveness and endorsing a more robust enforcement posture toward loyalty breaches would undercut the contractarian conflation of both duties as mere "default" rules, preventing erosion of the duty of loyalty. ${ }^{141}$

Delaware corporate law would be well served by a clearer analytical distinction between duties of care and loyalty and the enforcement of each, but the question of whether the duty of care ought to be reconceptualized in nonfiduciary terms would remain open. The statutory damages rule that I advocate would not require such a move and-the historical argument presented earlier in this Essay notwithstanding - there would be quite legitimate reasons to question the wisdom of such a move today. While the distinct

139. See Bruner, supra note 1 , at 1136.

140. Id. at 1177-78. While adoption of a statutory provision like that advocated here would render the BJR superfluous in assessing monetary liability exposure, courts might reasonably retain the BJR (or something like it) in the context of injunctive proceedings to the degree that concerns regarding institutional competence counsel nonreview of business decision making. See, e.g., Joy v. North, 692 F.2d 880, 886 (2d Cir. 1982) ("[C]ourts recognize that after-the-fact litigation is a most imperfect device to evaluate corporate business decisions. The circumstances surrounding a corporate decision are not easily reconstructed in a courtroom years later, since business imperatives often call for quick decisions, inevitably based on less than perfect information."). But see Johnson, Unsettledness in Delaware Corporate Law, supra note 78 (manuscript at 24-25, 31-32, 57) (arguing that the BJR amounts to "doctrinal surplusage" better conceptualized as an aspect of care analysis).

141. Recall that the statutory provision advocated would define loyalty "to include cases involving financial conflicts of interest, other improper personal benefits, conscious malfeasance, and conscious nonfeasance," capturing in the last of these categories the set of cases now viewed by the Delaware courts as involving "bad faith omission." The loyalty concept, so defined, effectively embraces all of the exceptions to exculpation listed in the present $\S 102(\mathrm{~b})(7)$. See Del. Code ANN. tit. 8, § 102(b)(7) (2012); Bruner, supra note 1, at 1136-37, 1178-79. While not taken up here, to the extent that $\S 102(\mathrm{~b})(7)$ itself represents the current impediment to waiving the duty of loyalty in a Delaware corporate charter, the statutory damages provision advocated here should likewise expressly bar waiver in order to ensure continuity on this point. See, e.g., R. Franklin Balotti \& Jesse A. Finkelstein, The Delaware law of CORPORATIONS AND BUSINESS ORGANIZATIONS $\S 4.16$, at 4-119 (3d ed. 2009) ("The boundaries of the duty of loyalty are increasingly important in light of Section 102(b)(7) ..."). 
origins, nature, moral valences, and instrumental logic of these duties are certainly consequential, and while the arguments for styling the duty of care differently would appear strong if we were writing on a clean slate, the fact is that we are not writing on a clean slate.

Even if monetary damages were expressly unavailable, there might nevertheless be reason to believe that styling the duty of care "fiduciary" in nature could enhance compliance, assuming (plausibly enough) that the marketplace invests that label with heightened significance. As Tamar Frankel has observed, "if law is earmarked as a separate category, the importance of the problems it addresses is highlighted." 142 This dynamic may loom particularly large with usage of the "fiduciary" label, as "a moral taint of violating fiduciary duties appears in many areas" of U.S. law-contrasting sharply with the prevailing view of "contract breach as an amoral act."143 In this light, calling the duty of care a "fiduciary" duty for decades and then abruptly restyling it as something else might be misinterpreted by the marketplace as a de facto demotion-undercutting compliance stemming from motivations other than fear of monetary damages. ${ }^{144}$

More generally, it must be acknowledged that we need not style such legal concepts in any particular way simply because they were styled that way in earlier times (or in other places). ${ }^{145}$ Indeed, even in other common law jurisdictions treating loyalty as the sole fiduciary duty, there are those who question whether legal and equitable remedies can in fact be so neatly and categorically distinguished as the Mothew decision suggests, ${ }^{146}$ and, likewise, whether there is truly nothing distinctly "fiduciary" about the duty

142. FRANKEL, supra note 57 , at 235 .

143. Id. at 238. Cf. Birks, supra note 44 (conceding that "[w]e might say that [care] is not especially fiduciary" relative to loyalty, but arguing that "care in the affairs of the beneficiary is the very heart of the trustee's obligation"). It should be noted that the lower moral valence associated with contract breach is unique to common law jurisdictions. As Frankel observes, in civil law jurisdictions rejecting the bifurcation of "legal" and "beneficial" title to property, effective fiduciary relationships can nevertheless be created through contract. Tamar Frankel, Towards Universal Fiduciary Principles 6-10 (2013) (unpublished manuscript) (on file with author). "Civil Law contract is suitable to cover fiduciary relationships," she explains, because "Civil Law contract rules carry a high degree of moral requirements, and breach of contract by trusted parties is considered highly immoral." Id.

144. Cf. Julian Velasco, The Role of Aspiration in Corporate Fiduciary Duties, 54 WM. \& MARY L. REv. 519, 519, 523 (2012) (arguing that "fiduciary duty standards of conduct are duties-fully binding on actors even when they are not enforced"); see also id. at 555 (rejecting use of the term "aspirational" to describe the duty of care because it "is highly suggestive of optionality, and possibly even unachievability").

145. Cf. FrankeL, supra note 57, at 240 (arguing that the origins of fiduciary law are "not decisive today," as "the approaches and limitations of the past are not necessarily appropriate today").

146. See, e.g., Burrows, supra note 44. 
of care (or at least its application) in the context of fiduciary relations. ${ }^{147}$ In this light, it behooves me to emphasize what is truly at issue in designing a monetary liability regime for the specific context of corporate law. What is required is a clear and effective means of distinguishing the realm of loyalty breaches, where the potential for monetary recovery from directors is to be favored, from the realm of care breaches, where the potential for monetary recovery from directors threatens to deliver more harm than good. As I have explored above, this distinction flows from the very different analytical and moral posture the director occupies in these contrasting settings-and while the fiduciary/nonfiduciary distinction drawn in the United Kingdom, Australia, and Canada provides one mechanism by which this distinction may be established and maintained, it is certainly not the only possibility. A statutory damages provision of the sort advocated here would, I submit, fit the bill nicely.

I accept the force of the foregoing arguments regarding perceived demotion of the duty of care and do not consider the statutory damages rule advocated here to be in tension with their fundamental aims; a statutory damages rule need not alter the articulation or conceptualization of the underlying duty itself. 148 Indeed, a clear damages rule like that advocated here could actually facilitate a more robust formulation of the underlying duty of care, because articulation of a stronger standard of conduct would no longer be muted or inhibited by risk-aversion concerns, or otherwise impacted by interaction with the BJR. ${ }^{149}$

Were Delaware to continue treating both care and loyalty as two reflections of some singular, underlying "fiduciary" concept, however, the need would be all the more pressing for a statutory provision clarifying the critical enforcement distinction discussed here and foreclosing their conflation in a categorical manner. As the foregoing analysis demonstrates, the costs of conflating the duties of care and loyalty have been quite real, and without a statutory response, the costs may well continue to rise.

147. See, e.g., Miller, supra note 6 , at 281-85.

148. This would appear to be a corollary of Julian Velasco's argument that "fiduciary duty standards of conduct are duties-fully binding on actors even when they are not enforced." See Velasco, supra note 144, at 523.

149. Cf. Johnson, supra note 10, at 803-05 (arguing that subsuming the duty of care within the BJR had the effect of diminishing the substantive duty by "wrongly correlat[ing] the duty of due care with the informedness element of the business judgment rule"). 